\title{
IAMJ
}

INTERNATIONAL

AYURVEDIC

MEDICAL JOURNAL

\section{A COMPARATIVE CLINICAL STUDY OF KADALI KSHARA AND KSHARA IN THE MANAGEMENT OF CHARMAKEELA (WARTS)}

\author{
Aqlak Husen Badami ${ }^{1}$, N. B. Mashetti ${ }^{2}$, P. G. Gannur ${ }^{3}$, Rakeshkumar Gujjar \\ ${ }^{1}$ P.G. Scholar, Department of Shalyatantra \\ ${ }^{2}$ Professor and HOD Department of Shalyatantra \\ ${ }^{3}$ Associate Professor Department of Shalyatantra, \\ ${ }^{4}$ Assistant professor Department of Shalyatantra. \\ BLDEA’s AVS Ayurveda MahavidyalayaVijayapur, Karnataka, India
}

Corresponding Author: draqlakhusen@gmail.com

https://doi.org/10.46607/iamj0808102020

(Published online: October 2020)

Open Access

(C) International Ayurvedic Medical Journal, India 2020

Article Received:12/09/2020 - Peer Reviewed: 28/09/2020 - Accepted for Publication: 03/10/2020

\section{(A) Check for updates}

\section{ABSTRACT}

Charmakeela is one of the Kshudraroga mentioned by Acharya Sushrutha and Vagbhata. Vyanavata combines with Kapha produces piles on the exterior of the skin resembling a nail which is static or immovable and rough is called as Charmakeela. Based upon the clinical features explained in Ayurveda, Charmakeela can be correlated with that of warts. Objective: The present study was to evaluate the comparative effect of Kadalikshara and Apamargakshara in the management of Charmakeela. Methods: 40 patients were randomly selected and divided into 2 groups. Results: The statistical Analysis the study reveals there is no significant difference between found statistically between Kadalikshara and Apamargakshara, so both KadaliKshara and ApamargaKshara are having same Qualitative Equanimity effect of treatment on the disease. Conclusion: As observed from the results the total removal of Charmakeela was possible in all cases and it proves the authenticity of the classical ayurvedic reference which state that Charmakeela can be removed by the application of Prathisarneeyakshara. In this study the action of the drugs KadaliKshara and ApamargaKshara on the removal of Charmakeelais well established. The clearance may be faster in case of thin lesions and it may be slower in case of thicker lesion because of varia- 
tions in the thickness of morbid growth in all patient, removal of lesion of Charmakeela there may be slight blackish brown discolouration occurs at the site of lesion was observed. This may be considered as Samyakdagdhalaxanas of Kshara Karma which will disappear gradually.

Keywords: Apamargakshara, Charmakeela, Kshudraroga, Kshara Karma, Samyakdagdhalaxanas

\section{INTRODUCTION}

Charmakeela is one of the Kshudra roga $a^{l}$ mentioned by Acharya Sushrutha and Vagbhata. Vyanavata combines with Kapha produces piles on the exterior of the skin resembling a nail which is static or immovable and rough is called as Charmakeela. With predominant of vata it is painful and rough, with Pitta it is blackish and red with Kapha it is greasy, knotty and of the same colour of skin. ${ }^{2}$ Black, painless, sprouts on the skin resembling like Tila are known as Tilakalka. These only are known as Masaka when they are raised. More projecting than Masaka is known as Charmakeela. ${ }^{3}$ Based upon the clinical features explained in Ayurveda, Charmakeela can be correlated with that of warts.In present days people all over the world are very conscious towards their looks. From cosmetic point of view, warts are troublesome. Morphological non genital warts comprised common (42\%), palmoplantar $(20 \%)$, plane $(18 \%)$, mosaic $(6 \%)$, and Filliform (4\%). Extremities were the most common sites $(66.7 \%)$; face was the next commonly $(23 \%) .{ }^{4}$ Warts are patches of hyperkeratotic overgrown skin; such overgrown of skin is often stimulated by virus. Warts may occur at any age but are common in children, adolescents and young adults the symptoms are usually disfiguring. Multiple warts in the finger may interfere in movements. Warts are only painful if they are rubbed or become infected. ${ }^{5}$ Sushruta mentioned chikitsa of Charmakeela with Pratisarneeya kshara. ${ }^{6}$ Vagbhata mentioned the chikitsa of Charmakeela with Agni karma and kshara karma. ${ }^{7}$ as, recurrence rate is more in Aushadha \& chedana karma (shastra karma). So here an attempt is made to manage Charmakeela with Pratisarneeyakshara karma. Kshara does ksharana and kshanana. ${ }^{8}$ Kshara performs the action like Chedana, Bedhana, Lekhana, etc. ${ }^{9}$ the comparison and clinical effect of Kadalikshara and Apamargakshara is to be studied, so present study is very much needed to explore new facts and figures in this area. The study will be carried out to evaluate the clinical effect of Kadalikshara and Apamargakshara in charmakeela (Warts).

\section{Materials and Methods}

Totally 40 patients of Charmakeela selected and divided into two groups, Group A-20 and Group B-20 patients. Complete history and clinical evaluation of the patients of Charmakeela recorded in the special designed case sheet. Subjective and Objective parameters were used to assess the clinical response in both the groups. The patients were assessed on before treatment, on $1^{\text {st }}$ day after treatment, $7^{\text {th }}$ day after treatment, $15^{\text {th }}$ day after treatment.

GROUP- A:-Patients will be treated with Tikshna Kadali Kshara after lekhana karma.

GROUP- B:-Patients will be treated with Tikshna Apamarga Kshara after Lekhana karma.

Kshara Karma - One sitting.

Source Of Data: Study will be carried out on the diagnosed patients of Charmakeela attending O.P.D \& I.P.D. of B.L.D.E.A's AVS Ayurveda Mahavidyalaya Hospital and Research centre, Vijayapur.

Inclusion Criteria: Patients aged between 18-60 years., Patients of either sex are taken., Patient with clinical features of Charmakeela (warts).

Exclusion Criteria: Patients suffering from systemic disorders like- Diabetes Mellitus, Hypertension and other systemic diseases. Patient contraindicated for Kshara Karma.

\section{Observation and Results}

\section{Pain}

Group A: BT to Follow up on $1^{\text {st }}$ day after treatment mean is $0.4(33.3 \%)$, $\mathrm{p}$ value $-\mathrm{P}>0.05$ insignificant. BT to follow up on $7^{\text {th }}$ Day After Treatment mean is $0.4(50 \%), p$ value $-p>0.05$ insignificant. BT to follow up on $15^{\text {th }}$ Day After Treatment mean is 0.7 
(87.5\%), $\mathrm{p}$ value $-\mathrm{p}<0.05$ significant. Group B: BT to Follow up on $1^{\text {st }}$ day after treatment mean is 0.05 $(5 \%)$, $\mathrm{p}$ value $-\mathrm{P}>0.05$ insignificant. $\mathrm{BT}$ to follow up on $7^{\text {th }}$ Day After Treatment mean is $0.4(40 \%)$, p value - $p>0.05$ insignificant. BT to follow up on $15^{\text {th }}$ Day After Treatment mean is 0.95 (95\%), p value $\mathrm{p}<0.001$ Highly significant. Statistically it was found there is no any significant difference in pain between Group A \& Group B so Kadalikshara shows equal result in pain management as that of Apamargakshara.

\section{Burning Sensation}

Group A: BT to Follow up on $1^{\text {st }}$ day after treatment mean is $0.6(---\%)$, $\mathrm{p}$ value $-\mathrm{P}<0.05$ Significant. BT to follow up on $7^{\text {th }}$ Day After Treatment mean is 0.1 (25\%), p value - $p>0.05$ Insignificant. BT to follow up on $15^{\text {th }}$ Day After Treatment mean is $0.4(100 \%)$, p value $-p<0.05$ Significant, Group B: BT to Follow up on $1^{\text {st }}$ day after treatment mean is 0.06 , $\mathrm{p}$ value $-\mathrm{P}$ $<0.05$ Significant. BT to follow up on $7^{\text {th }}$ Day After Treatment mean is $0.15(75 \%)$, $p$ value $-p>0.05$ Insignificant. BT to follow up on $15^{\text {th }}$ Day After Treatment mean is $0.02(100 \%), p$ value $-p>0.05$ Insignificant, This shows that statistically it was found there is no any significant difference in Burning Sensation between Group A \& Group B so Kadalikshara shows equal result in management of Burning Sensation as that of Apamargakshara.

\section{Itching}

Group A: BT to Follow up on $1^{\text {st }}$ day after treatment mean is 0.15 (27\%), p value $-\mathrm{P}>0.05$ Insignificant. BT to follow up on $7^{\text {th }}$ Day After Treatment mean is 0.3 (54.5\%), $p$ value - $p>0.05$ Insignificant. BT to follow up on $15^{\text {th }}$ Day After Treatment mean is 0.5 (91\%), $p$ value $-p>0.5$ Insignificant Group B: BT to Follow up on $1^{\text {st }}$ day after treatment mean is 0.2 (44\%), p value $-\mathrm{P}>0.05$ Insignificant. BT to follow up on $7^{\text {th }}$ Day After Treatment mean is $0.25(55.5 \%)$, $p$ value $-p>0.05$ Insignificant. BT to follow up on $15^{\text {th }}$ Day After Treatment mean is 0.45 (100\%), p value $\mathrm{p}>0.05$ Insignificant

This shows that statistically it was found there is not any significant difference in Itching between Group A
\& Group B so Kadalikshara shows same result in management of Itching as that of Apamargakshara.

\section{Size}

Group A: BT to Follow up on $1^{\text {st }}$ day after treatment mean is $0.05(5 \%)$, $\mathrm{p}$ value $-\mathrm{P}>0.05$ Insignificant. BT to follow up on $7^{\text {th }}$ Day After Treatment mean is $0.7(63.6 \%)$, $p$ value $-p>0.05$ Insignificant. BT to follow up on $15^{\text {th }}$ Day After Treatment mean is 0.9 $(81.8 \%)$, $p$ value $-p>0.5$ Insignificant, Group B: BT to Follow up on $1^{\text {st }}$ day after treatment mean is $0(0 \%)$, $\mathrm{p}$ value $-\mathrm{P}>0.05$ Insignificant. $\mathrm{BT}$ to follow up on $7^{\text {th }}$ Day After Treatment mean is $0.45(42.8 \%)$, p value $\mathrm{p}>0.05$ Insignificant. BT to follow up on $15^{\text {th }}$ Day After Treatment mean is $0.75(71 \%), p$ value $-p<0.01$ Highly Significant, This shows that statistically it was found there is no any significant difference in between size Group A \& Group B so Kadalikshara shows same result in reduction of size as that of $\mathrm{Apa}$ margakshara.

\section{Knottiness}

Group A: BT to Follow up on $1^{\text {st }}$ day after treatment mean is $0.25(22.7 \%)$, p value $-\mathrm{P}>0.05$ Insignificant. BT to follow up on $7^{\text {th }}$ Day After Treatment mean is $0.75(68 \%)$, $p$ value $-p<0.01$ Highly Significant. BT to follow up on $15^{\text {th }}$ Day After Treatment mean is 0.9 $(81.8 \%)$, $p$ value $-p<0.001$ Highly Significant.

Group B: BT to Follow up on $1^{\text {st }}$ day after treatment mean is $0.05(4.5 \%)$, p value $-\mathrm{P}>0.05$ Insignificant. BT to follow up on $7^{\text {th }}$ Day After Treatment mean is $0.5(45.4 \%)$, $p$ value $-p>0.05$ Insignificant. BT to follow up on $15^{\text {th }}$ Day After Treatment mean is 0.8 (72.7\%), p value $-p<0.001$ Highly Significant: Statistically it was found Knottiness Group A \& Group B i.e., Kadalikshara shows highly significant result in reduction of Knottiness as that of Apamargakshara.

Overall Results of Subjective and Objective Parameters Within Groups

The mean $( \pm$ S.D) of overall results in Group A is 3.95( $\mathrm{SD}=0.89)$ before treatment and $0.55(0.83)$ after treatment there is $86 \%$ of reduction in parameters and $p<0.001$ which is Highly Significant

The mean $( \pm$ S.D) of overall results in Group B is $3.8(\mathrm{SD}=0.89)$ before treatment and $0.65(1.04)$ after 
treatment there is $82.9 \%$ of reduction in parameters and $\mathrm{p}<0.001$ which is Highly Significant

KadaliKshara Shows Highly Significant Result in Management of Charmakeela As That ofApamargaKshara. So, Both Are Qualitative equanimity effect on the disease

\section{DISCUSSION}

Charmakeela is one of the Kshudra roga $a^{l}$ mentioned by Acharya Sushrutha and Vagbhata. Vyanavata combines with Kapha produces piles on the exterior of the skin resembling a nail which is static or immovable and rough is called as Charmakeela. Warts are patches of hyperkeratotic overgrown skin; such overgrown of skin is often stimulated by virus. Vagbhata mentioned the chikitsa of Charmakeela with Agni karma and kshara karma as, recurrence rate is more in aushadha\&chedana karma (shastra kar$m a$ ). So here an attempt is made to manage Charmakeela with Pratisarneeyakshara karma. Charmakeela is a disease which is found commonly now a day in above study it is shown that it mainly affects middle class (90\%). So, the treatment Kshara Karma is very simple, economic and safe. Kshara is with Ag$n i$ and Vayumahabhootadikyata hence having teekshnata and corrosive properties with quick action. It is having qualities like Chedana, Bhedana, Lekhana etc. Kshara having mainly Lavana (salty), Tikta (bitter) Rasas in predominant Ruksha (dry), Tikshna Guna (properties); Ushna (hot) Virya (potency); and Katu (pungent) Vipaka (attributes of drug assimilation). Kshara has possessed the Chedana (excision), Bhedana (incision) Properties along with various other therapeutic actions. Thus, they are used in different diseases Because of more hydroxides present in kshar by external application it may reduce the size of knots with cauterization and finally removes knots in short period without giving any pain. This acts as chemical cauterization.

\section{CONCLUSION}

By the statistical Analysis the study reveals there is no significant difference between found statistically between Kadalikshara and Apamargakshara, so both
KadaliKshara and ApamargaKshara are having same Qualitative Equanimity effect of treatment on the disease. KadaliKshara is found to be same effective as that of ApamargaKshara. The normal texture of skin was regained without any deformity. This is a good result in the management of Charmakeela considering the fact this will be cosmetically beneficial. The procedure is simple, economical and could be conducted in O.P.D and minor O.T. Hospitalization was not necessary. No adverse effect was found during study in both Group A and Group B.As observed from the results the total removal of Charmakeela was possible in all cases and it proves the authenticity of the classical ayurvedic reference which state that Charmakeela can be removed by the application of Prathisarneeyakshara. In this study the action of the drugs Kadali Kshara and Apamarga Kshara on the removal of Charmakeela is well established. The clearance may be faster in case of thin lesions and it may be slower in case of thicker lesion because of variations in the thickness of morbid growth in all patient, removal of lesion of Charmakeela there may be slight blackish brown discolouration occurs at the site of lesion was observed. This may be considered as Samyakdagdhalaxanas of kshara karma which will disappear gradually.

\section{REFERENCES}

1. Murthy, S. Vagbhata's Ashtanga Hrdayam. 1st ed. Varanasi: Chowkhamba Krishnadas Academy (2014). Uttarsthana chapter 31, pg-295

2. Murthy, S. Vagbhata's Ashtanga Hrdayam. 1st ed. Varanasi: Chowkhamba Krishnadas Academy (2014). Nidanastana chapter-7, sloka-57-58, pg-75

3. Murthy, S. Vagbhata's Ashtanga Hrdayam. 1st ed. Varanasi: Chowkhamba Krishnadas Academy (2014). Uttarsthana chapter 31, sloka-25-26, pg-295

4. Shruti S. St. All. http://dx.doi.org/10.115/2016/7989817. clinicoepidemological study of different types of warts

5. Das, S. A concise Textbook of Surgery. 4th ed. Culcutta: Dr. S. Das.

6. Mehata (2006) P.chapter-10, pg-122

7. Sushtruta Samhita of Maharshi Sustruta edited with Ayurveda tattva sandipikahindi commentary by Kaviraj Shastri. 1st ed. Varanasi: Chaukhamba Sanskrit 
Sansthan. Suthrasthana (2014). Chapter-11, sloka-7, pg-46.

8. Murthy, S. Vagbhata's Ashtanga Hrdayam. 1st ed. Varanasi: Chowkhamba Krishnadas Academy (2014). Uttarsthana chapter 32, sloka13-14, pg-301

9. Sushtruta Samhita of Maharshi Sustruta edited with Ayurveda tattva sandipikahindi commentary by Kaviraj Shastri. 1st ed. Varanasi: Chaukhamba Sanskrit Sansthan. (2014). Suthrasthana chapter-11, sloka-4, pg 45 .

\section{Source of Support: Nil \\ Conflict of Interest: None Declared}

How to cite this URL: Aqlak Husen Badami et al: A Comparative Clinical Study Of Kadali Kshara And Apamarga Kshara In The Management Of Charmakeela (Warts). International Ayurvedic Medical Journal \{online\} 2020 \{cited October, 2020\} Available from: http://www.iamj.in/posts/images/upload/4617_4621.pdf 